\title{
STRATEGI PENGEMBANGAN DESA PANGSAN SEBAGAI DESA WISATA DI KECAMATAN PETANG KABUPATEN BADUNG
}

\author{
Putu Agus Wikanatha Sagita \\ wikanatha_s@yahoo.com \\ Dosen Fakultas Pariwisata Unud
}

\begin{abstract}
The development of tourism in Badung Regency which is focused in South Badung needs to be equalized by developing the potentials of the rural areas, one of which is Pangsan Village, as superiority in North Badung; otherwise, tourism will never equally benefit all the areas. However, the potentials the Pangsan Village has in tourism have not been developed yet.

This study aims at (1) identifying the potentials as a tourist attraction; (2) analyzing the internal and external environment, and (3) formulating the strategies used and programs created to develop Pangsan Village as a tourist destination. The result of analysis of internal and external environment indicated that Pangsan Village was categorized as fair (on cell $V$ ), that is using the general strategies of market penetration and product development. From the SWOT analysis, the alternative strategies were the SO (Strengths Opportunities) strategy which could be tourism product development and market penetration; the ST (Strengths Threats) which could be applied by improving security and comfort, and strengthening the specific characteristics of Pangsan Village; the WO (Weaknesses Opportunities) strategy which could be applied by developing the basic and supporting facilities and infrastructure, strengthening collaboration and promotion; the WT strategy (Weaknesses Threats) which could be applied by developing the human resources and the groups that were aware of tourism "Kelompok Sadar Wisata".
\end{abstract}

Keywords: equality of usefulness of tourism, developmental strategy, tourist village 


\section{Pendahuluan}

Sebagai ikon pariwisata Indonesia, Bali telah menjadi salah satu daerah tujuan wisata dunia yang sangat populer. Pariwisata bahkan menjadi komoditas yang mampu menggantikan sumber daya tambang dan minyak sebagai penggerak roda perekonomian di pulau dewata. Kabupaten Badung merupakan salah satu dari delapan Kabupaten di Bali dengan Pendapatan Asli Daerah (PAD) tertinggi yang didapat dari sektor pariwisata.

Selama ini Kabupaten Badung dikenal dengan kawasan wisata Kuta serta Nusa Dua yang telah tersohor sebagai destinasi wisata unggulan yang menikmati pesatnya pembangunan pariwisata. Kondisi berbeda terlihat di Badung bagian Utara yang menyimpan potensi keindahan alam serta kehidupan perdesaan yang masih tradisional. Jika dilihat dari tingkat kesejahteraan masyarakatnya, dapat dikatakan daya beli masyarakat Badung Selatan yang mayoritas bergerak di sektor pariwisata jauh lebih baik dibandingkan dengan masyarakat Badung Utara yang hidup dengan memanfaatkan tanah pertanian dan perkebunan yang dimiliki. Melihat ketimpangan kesejahteraan yang terjadi, maka dipandang perlu untuk menerapkan suatu model pariwisata berkelanjutan yang dapat memberikan manfaat positif pariwisata dengan lebih merata. Salah satu upaya yang dapat dilakukan adalah dengan mengangkat potensi desa yang menjadi unggulan di wilayah Badung Utara. Tujuan pariwisata berkelanjutan dapat dicapai dengan menyeimbangkan nilai sosial, lingkungan dan ekonomi. Terdapat keinginan untuk melindungi dan menonjolkan alam serta membangun keistimewaan untuk mengembangkan dan memasarkan daerah tujuan wisata dengan tepat. Hal yang tidak kalah penting adalah memastikan pariwisata yang konsisten dengan nilai-nilai serta aspirasi masyarakat guna memberikan kontribusi positif terhadap pembangunan dan kesejahteraan masyarakat itu sendiri (Wray et. al., $2010: 32$ ).

Desa Pangsan merupakan salah satu desa wisata yang terletak di Kecamatan Petang Kabupaten Badung. Desa tersebut memiliki potensi alam maupun budaya yang cukup menjanjikan untuk pengembangan pariwisata. Atraksi wisata andalan di Desa Pangsan adalah Sungai Ayung yang terkenal dengan arusnya yang menantang. Sungai sepanjang \pm 68 km ini memisahkan antara Kecamatan Ubud di Kabupaten Gianyar dan Kecamatan 
Petang di Kabupaten Badung. Sejak tahun 1997 sungai ini telah dimanfaatkan untuk melakukan olah raga arung jeram. Selain itu, Hamparan sawah dan perkebunan yang terbentang hampir di setiap banjar merupakan atraksi pariwisata yang sudah semakin sulit ditemukan di daerah perkotaan. Namun untuk saat ini, kunjungan maupun hasil yang didapat dari aktivitas pariwisata perdesaan belumlah sesuai dengan harapan, sehingga belum mampu memberikan kesejahteraan bagi masyarakat lokal secara optimal.

Berdasarkan latar belakang tersebut maka permasalahan yang diangkat dalam penelitian ini adalah: (1). Apa saja potensi daya tarik pariwisata yang terdapat di Desa Pangsan ? (2). Bagaimanakah kondisi lingkungan internal dan eksternal dalam pengembangan Desa Pangsan sebagai desa wisata ? (3). Bagaimanakah strategi dan program pengembangan Desa Pangsan sebagai desa wisata ?. Hasil dari penelitian ini diharapkan dapat memberikan gambaran serta masukan kepada pemerintah, industri pariwisata, serta masyarakat setempat dalam upaya pengembangan Desa Pangsan sebagai desa wisata.

\section{Tinjauan Konsep dan Teori}

\subsection{Strategi Pengembangan}

Menurut Marpaung (2002 : 96), strategi dapat diartikan sebagai rencana umum yang bersifat integrative yang dirancang untuk memampukan organisasi pariwisata untuk mencapai tujuannya melalui alokasi pemanfaatan sumber daya dengan tepat walaupun menemukan banyak rintangan dari pihak pesaing. Berdasarkan pendapatnya, Alwi (2005 : 538) dalam Kamus Besar Bahasa Indonesia menyatakan bahwa pengembangan merupakan suatu proses, cara, perbuatan menjadikan sesuatu menjadi lebih baik, maju, sempurna dan berguna. Pengembangan merupakan suatu proses / aktivitas memajukan sesuatu yang dianggap perlu untuk ditata sedemikian rupa dengan meremajakan atau memelihara yang sudah berkembang agar menjadi lebih menarik dan berkembang. 


\subsection{Desa Wisata}

Menurut Suwatoro (1997) desa wisata adalah suatu wilayah pedesaan yang menawarkan keseluruhan suasana yang mencerminkan keaslian pedesaan baik dari tata ruang, arsitektur, bangunan, maupun pola kehidupan sosial-budaya masyarakat, adat istiadat keseharian serta mampu menyediakan komponen-komponen kebutuhan pokok wisatawan seperti akomodasi, makanan dan minuman, cinderamata, dan atraksi-atraksi wisata. Dalam desa tersebut juga mampu menyediakan dan memenuhi serangkaian kebutuhan suatu perjalanan wisata, baik dari aspek daya tarik maupun berbagai fasilitas pendukungnya. Adapun unsur-unsur dari desa wisata adalah :

1. Memiliki potensi pariwisata, seni dan budaya khas daerah setempat

2. Lokasi desa masuk dalam lingkup daerah pengembangan pariwisata atau setidaknya berada dalam koridor dan rute perjalanan wisata yang sudah dijual

3. Diutamakan sudah tersedia tenaga pengelola, pelatihan dan pelaku-pelaku pariwisata yang sudah dijual

4. Aksesibilitas dan infrastruktur mendukung program desa wisata

5. Terjaminnya keamanan, ketertiban, dan kebersihan (Prastyo, $2005: 33$ )

\subsection{Pembangunan Pariwisata Berkelanjutan}

United Nation World Commision on Environment and Development / UNWCED dalam Purba (2002), menyatakan bahwa pembangunan berkelanjutan adalah pembangunan yang dapat memenuhi kebutuhan masyarakat dimasa sekarang tanpa menghambat kemampuan generasi mendatang untuk memenuhi kebutuhannya. Disini ditekankan pentingnya keterkaitan antara kependudukan, sumber daya dan lingkungan serta perlunya memperhatikan kelangsungan keterkaitan antar manusia, sumber daya dan pembangunan.

\subsection{Permintaan dan Penawaran dalam Kepariwisataan}

Menurut Wahab dalam Yoeti (2008 : 125 - 127), penawaran dalam industri pariwisata dapat dibagi menjadi 2, yaitu yang berasal dari alam (Natural amenities) dan 
buatan manusia (Man-made supply). Permintaan terhadap produk industri pariwisata juga dapat dibagi atas dua bagian yang penting, yaitu permintaan potensial (potential demand) dan permintaan yang sebenarnya terjadi (actual demand).

\subsection{Teori Perencanaan}

Menurut Inskeep (1991 : 29), proses perencanaan dasar menyediakan kerangka perencanaan yang umum, dan menekankan pada konsep perencanaan menjadi berkesinambungan, berorientasi sistem, menyeluruh, terintegrasi, dan lingkungan dengan fokus pada keberhasilan pengembangan yang dapat mendukung keterlibatan masyarakat.

\subsection{Teori Siklus Hidup Destinasi Wisata}

Sedangkan, dalam teori siklus hidup destinasi wisata (Butler, $2006: 5-8$ ) dipaparkan tujuh fase dalam pengembangan destinasi wisata, yaitu Exploration, Involvemen,Development, Consolidation, Stagnation, Decline, dan Rejuvenation.

\subsection{Teori Pengelolaan Sumber Daya Berbasis Komunitas}

Korten (1986) mengungkapkan bahwa pembangunan kerakyatan adalah sebagai produk dan prakarsa kreatif masyarakat dengan tujuan untuk mewujudkan pemberdayaan. Hal tersebut diperkuat oleh Natori (2001 : 44) yang mengatakan bahwa pengelolaan sumber daya berbasis komunitas adalah aktivitas masyarakat untuk mempromosikan daerahnya melalui pertukaran dan penciptaan kreasi masyarakat melalui sumber daya lokal yang ada secara penuh dan memanfaatkan alam, budaya, sejarah, industri, orang-orang yang berbakat, dan sumber daya lokal lainnya.

\section{Metode Penelitian}

Berdasarkan permasalahan yang dirumuskan maka pendekatan penelitian ini menggunakan metode kualitatif. Pengumpulan data adalah prosedur yang sistematis dan standar untuk memperoleh data, yang dilakukan dengan pengamatan langsung ke lapangan (data primer), maupun data yang didapat dari suatu lembaga yang dengan tujuan tertentu 
telah menggali data tersebut sebelumnya (data sekunder) (Nasir, 1988). Pengumpulan data dilakukan dengan melakukan observasi, wawancara mendalam, angket, dan studi kepustakaan. Responden penelitian untuk pembobotan dan penilaian lingkungan internal dan eksternal ditentukan dengan purposive sampling yang berasal dari unsur pemerintah, praktisi, dan akademisi. Sedangkan responden dari wisatawan ditentukan dengan metode quota sampling. Keseluruhan renponden berjumlah 32 yang mewakili sisi supply dan demand dalam pengembangan Desa Pangsan sebagai desa wisata. Teknik analisis data yang dipakai adalah deskriptif kualitatif yang dibantu dengan matriks IFAS-EFAS dan analisis SWOT.

\section{Pembahasan}

\subsection{Potensi Daya Tarik Desa Pangsan}

Hasil dari penelitian ini menunjukkan bahwa Desa Pangsan memiliki potensi dan daya tarik pariwisata yang dapat dibagi menjadi 2, yaitu :

\subsection{Potensi Alam}

Potensi alam di Desa Pangsan berupa panorama persawahan dan perkebunan yang dihubungkan oleh jalan setapak yang masih alami dan terbilang cukup lebar. Selain itu kondisi udara desa yang sejuk akan membuat tubuh menjadi segar dan tidak cepat lelah, sehingga sangat cocok bagi pengembangan paket wisata di alam seperti tracking, cycling, jogging dsb. Selain village tour. Aktivitas wisata di Desa Pangsan tentunya tidak dapat terpisahkan dari keberadaan Sungai Ayung yang melintasi sebagian wilayah desa. Sungai sepanjang $\pm 68 \mathrm{~km}$ yang memisahkan Kecamatan Ubud dan Petang merupakan atraksi wisata yang sudah tidak asing bagi wisatawan pengggemar olah raga arung jeram. Hampir setiap hari wisatawan dari berbagai negara datang untuk mencoba serunya sensasi menaklukan arus Sungai Ayung yang menantang. Adapun rute dan tingkat derasnya arus sangat ditentukan oleh faktor cuaca dan start point yang ditawarkan oleh masing-masing usaha rafting. 


\subsection{Potensi Budaya}

Potensi budaya yang terdapat di Desa Pangsan berupa suasana perdesaan dan perumahan penduduk yang masih tradisional dan dibangun mengikuti nilai-nilai Agama Hindu yang biasa disebut Asta Kosala-Kosali. Potensi pariwisata di Desa Pangsan juga turut diperkuat dengan keberadaan 21 pura yang tersebar di masing-masing banjar. Keberadaan pura-pura tersebut diyakini berkaitan erat dengan sejarah pemerintahan Raja Jaya Pangus pada abab XII (ke-dua belas). Hal tersebut tertulis pada prasasti tembaga yang hingga saat ini masih tersimpan di Pura Penataran Agung Desa Pangsan. Setiap pura memiliki keunikan arsitektur yang berbeda-beda, bahkan diantaranya menyimpan mitosmitos yang merupakan kearifan lokal yang masih dipercaya oleh masyarakat setempat. Kemudian, potensi pariwisata yang perlu mendapat perhatian dalam pengembangan Desa Pangsan sebagai desa wisata berupa sebuah goa yang terletak di Banjar Pundung Desa Pangsan. Masyarakat setempat biasa menyebutnya sebagai Goa Perlindungan, mengingat fungsinya sebagai tempat perlindungan pada zaman perjuangan I Gusti Ngurah Rai pada saat terjadinya Agresi Militer Belanda II (ke-dua) oleh NICA (Netherlands India Civil Administration) yang ingin kembali menjajah Indonesia pasca ditandatanganinya Perjanjian Renville pada 17 Januari 1948. Seperti desa-desa pada umumnya di Bali, Desa Pangsan juga aktif mengembangkan seni budaya yang diwariskaan secara turun-temurun dalam bentuk pertunjukan yang bersifat hiburan dan juga seni yang disakralkan sebagai bagian dari rangkaian suatu upacara kegamaan yang saling melengkapi antara kegiatan ritual dan pementasan. Kesenian yang terdapat di Desa Pangsan, dapat dibagi menjadi 2 jenis, yaitu seni tari dan seni musik. Adapun seni tari yang terdapat di Desa pangsan, adalah tari barong, tari rejang dewa, dan tari calonarang yang termasuk jenis tari wali (tarian sakral); tari topeng, tari arja, wayang kulit yang termasuk jenis tari bebali (tarian semi sakral)); serta tari pendet, dan tari legong yang termasuk jenis tari balih-balihan (tarian hiburan). Seni musik di Desa Pangsan berada dalam naungan berbagai kelompok / sekaa kesenian yang telah dibentuk oleh masyarakat setempat, seperti Sekaa Gong Wanita, Sekaa Angklung, dan Sekaa Shanti. Disamping itu, Desa Pangsan juga menyimpan beberapa 
upacara khas yang mungkin tidak dapat dijumpai di tempat lain. Adapun beberapa upacara khas yang dimaksud, antara lain :

\section{Upacara Ngenar}

Merupakan upacara khas Desa Pangsan yang wajib dilakukan oleh anak-anak (wanita) sebelum masa puber. Anak yang dipilih biasanya berumur antara 9-10 tahun (Kelas 1 - Kelas 5 SD). Upacara ngenar diadakan setiap 6 bulan sekali, di Pura Puseh Pingit (Pura Penataran Agung). Adapun kegiatan yang dilakukan selama upacara, yaitu membuat bubuh (bubur), membuat tipat (ketupat), dan Mejejahitan (menjahit perlengkapan upacara). Tradisi turun-temurun masyarakat Desa Pangsan ini mempunyai keunikan tersendiri, karena pada saat upacara berlangsung, anak-anak hanya boleh didampingi oleh pemangku lanang. Orang dewasa yang sudah mengalami menstruasi atau telah berkeluarga dilarang untuk membantu. Bahkan untuk menengok berlangsungnya upacara pun tidak diperbolehkan. Jika hal tersebut dilanggar, maka upacara yang dilakukan akan gagal. Dalam artian, bubuh (bubur) yang dibuat sebagai sarana upacara yang utama akan hangus tanpa sebab.

\section{Upacara Kekembangan}

Merupakan sebuah upacara yang dilakukan oleh remaja Desa Pangsan yang membentuk sebuah perkumpulan diluar sekaa truna-truni yang disebut dengan truna daha. Perkumpulan tersebut khusus dibentuk dalam rangka pelaksanaan upacara yang diadakan setiap purnama di Pura Puseh Pingit. Adapun kegiatan yang dilakukan adalah membuat sajian yang dinamakan lampadan, yakni sejenis makanan yang dibuat dari sayuran yang mengandung unsur sad rasa / enam rasa, antara lain pakeh (asin), pait (pahit), manis, sepet (sepat), lalah (pedas), dan asem (masam). Upacara kekembangan dimulai dari hari persiapan, yaitu sehari sebelum hari purnama untuk mencari bahan-bahan yang akan diolah keesokan harinya. Bahan-bahan tersebut dicari diseluruh areal Desa Pangsan, termasuk di kebun milik warga. 


\section{Upacara Nyerahang Saye}

Merupakan upacara yang dilakukan oleh masyarakat Desa Pangsan yang telah dewasa / berkeluarga. Dalam rangka pelaksanaan upacara nyerahang saye, anggota masyarakat tersebut dibagi menjadi saye (kelompok kerja yang bertugas dan bertanggung jawab atas kelancaran upacara). Dalam pelaksanaannya, upacara ini memiliki keunikan khusus karena masyarakat desa diwajibkan untuk menghaturkan sajian yang dinamakan malang, yaitu olahan daging ayam cincang yang diberi bumbu berbahan dasar gula merah dan parutan kelapa.

Jika dilihat dari sudut pandang Agama Hindu, ketiga upacara khas tersebut merupakan bentuk penerapan konsep Tri Hita Karana dalam kehidupan masyarakat Desa Pangsan. Dilihat dari sisi palemahan, penggunaan bahan-bahan upacara yang diambil dari wilayah desa secara tidak langsung akan ikut melestarikan alam. Adanya kewajiban untuk melaksanakan upacara, dapat menimbulkan kesadaran masyarakat untuk menjaga dan memelihara berbagai tanaman yang bernilai sosial budaya sebagai sarana upacara yang belum tentu bisa ditemukan di daerah lain. Dilihat dari sisi pawongan, dapat diketahui bahwa ketiga jenis upacara mewakili kewajiban yang wajib dilakukan oleh masyarakat Desa Pangsan berdasarkan jenjang umurnya. Upacara Ngenar ditujukan bagi anggota masyarakat yang belum menginjak dewasa (anak-anak), upacara kekembangan diujukan bagi anggota masyarakat yang telah menginjak masa remaja, sedangkan upacara nyerahang saye ditujukan bagi anggota masyarakat yang telah dewasa. Keseluruhan upacara mengandung nilai kebersamaan dan saling tolong menolong diantara anggota masyarakat yang terlibat sehingga tercipta hubungan sosial yang harmonis. Sedangkan dari sisi parahyangan, dapat dilihat bahwa seluruh kegiatan upacara merupakan upaya dari masyarakat Desa Pangsan untuk melestarikan tradisi sebagai warisan turun-temurun dari leluhur mereka, sekaligus bentuk kesadaran masyarakat sebagai umat beragama untuk senantiasa mendekatkan diri dan membina hubungan baik dengan Tuhan. 


\subsection{Kondisi Lingkungan Internal dan Eksternal Desa Pangsan}

Adapun lingkungan internal berupa faktor-faktor kekuatan (strengths) Desa Pangsan, meliputi : panorama persawahan yang indah dan asri, irigasi pertanian dengan sistem subak, keramahtamahan masyarakat, jalur tracking, aneka vegetasi perkebunan, rafting, kehidupan tradisional masyarakat Desa Pangsan, dan lokasi strategis, sehingga mudah di akses dari daya tarik wisata lain. Faktor-faktor kelemahan (weaknesses), meliputi : kurangnya kualitas sumber daya manusia, kerjasama dan promosi yang belum optimal, pengembangan potensi pariwisata Desa Pangsan yang belum optimal, kurangnya sarana penunjang, seperti: homestay, tempat parkir, wc umum, pos jaga dan lain-lain, dan tidak adanya souvenir khas Desa Pangsan. Sedangkan lingkungan eksternal berupa faktor-faktor peluang (opportunities), meliputi : adanya trend pariwisata global kearah pariwisata perdesaan, kemajuan teknologi informasi dan transportasi, citra Bali sebagai DTW dunia, program Pemkab. Badung dalam pengembangan desa wisata, kerjasama dengan biro perjalanan wisata, agen perjalanan wisata, dan hotel, serta kerjasama dengan sekolahsekolah. Faktor-faktor ancaman (threats), meliputi : resesi ekonomi dunia, persaingan dengan daya tarik wisata sejenis, mewabahnya penyakit rabies dan flu burung, ancaman terhadap keamanan Bali, serta kondisi politik dan keamanan nasional yang kurang stabil. Setelah dianalisis menggunakan matriks internal dan eksternal didapatkan hasil bahwa Desa Pangsan berada pada sel V yang mengidikasikan Desa Pangsan dalam kategori baik atau memiliki peluang untuk berkembang.

\subsection{Strategi Pengembangan Desa Pangsan sebagai Desa Wisata}

Jika melihat keberadaan Desa Pangsan saat ini, maka strategi umum yang harus dilakukan dalam pengembangan Desa Pangsan sebagai desa wisata adalah strategi pertahankan dan pelihara, yaitu dengan melakukan penetrasi pasar dan pengembangan produk. Sedangkan strategi alternatif dalam pengembangan Desa Pangsan sebagai desa wisata, meliputi : 
1. Strategi SO (Strengths Opportunities) yaitu strategi pengembangan produk pariwisata yang dilakukan dengan 2 (dua) program. Pertama, program mengoptimalkan pengemasan produk wisata yang ada saat ini. Program tersebut dilaksanakan dengan mengembangkan produk wisata berbasis pertanian, melengkapi village tour dengan pembelajaran tanaman obat, dan menambah atraksi pembuatan alat-alat pertanian. Kedua, dengan program mengangkat atraksi wisata yang potensial. Program tersebut dilakukan dengan mengangkat potensi goa perlindungan yang merupakan peninggalan bersejarah pada zaman agresi militer Belanda II serta Membuat agrowisata yang dihimpun dalam wadah koperasi agar pengolahan hasil perkebunan lebih terorganisir, sekaligus dapat memberikan manfaat positif yang lebih bagi masyarakat dari sisi ekonomi. Selain itu, Desa Pangsan juga perlu melakukan strategi penetrasi pasar Eropa, yang dapat dilakukan dengan 2 program. Pertama, dengan memperluas pangsa pasar kepada negara Eropa lain seperti Jerman, Spanyol dan khususnya Belanda yang memiliki keterkaitan sejarah dengan Desa Pangsan mengingat keberadaan potensi Goa Perlindungan sebagai peninggalan sejarah pada Agresi Militer Belanda II. Kedua, dengan mengoptimalkan penggunaan teknologi informasi dan komunikasi seperti website dan e-tourism kiosk karena sifatnya yang low cost and high impact sangat sesuai dengan kondisi daya tarik wisata yang memiliki keterbatasan sumber daya.

2. Strategi ST (Strengths Threats) yaitu strategi peningkatan keamanan dan kenyamanan serta memperkuat ciri khas yang terdapat di Desa Pangsan, yang dilakukan dengan 3 (tiga) program. Pertama, program pengembangan jenis vegetasi pertanian dan perkebunan dengan melakukan budidaya tanaman sayuran dan buah-buahan organik, seperti tomat chery, jamur, pakhoy hijau, selada, bayam merah, dan kangkung. Begitu juga dengan pengembangan varietas tanaman obat seperti : daun dewa, sambiloto, temulawak, temu putri, mahkota dewa, akar wangi dsb. Hal tersebut tentunya diiringi dengan melakukan konservasi terhadap tanaman yang mengandung nilai sosial budaya yang biasa digunakan sebagai bahan pelengkap upacara. Kedua, program peningkatan keamanan dengan bekerjasama dengan pihak kepolisian maupun kemanan informal 
masyarakat di Desa Pangsan. Selain itu, dipandang perlu untuk membentukan satuan pengaman khusus yang menangani kemanan pariwisata di Desa Pangsan. Satuan pengamanan pariwisata ini dapat melibatkan masyarakat ataupun satuan pengaman yang sudah ada. Ketiga, program mengkemas atraksi wisata yang berkaitan dengan upacara khas Desa Pangsan seperti Upacara Ngenar, Kekembangan, dan Nyerahang Saye mengandung kearifan lokal yang erat kaitannya dengan nilai-nilai luhur Agama Hindu khususnya Tri Hita Karana.

3. Strategi WO (Weaknesses Opportunities) yaitu Strategi pengembangan sarana dan prasarana pokok maupun penunjang pariwisata, yang dilakukan dengan 3 (tiga) program. Pertama, program penyediaan fasilitas homestay memanfaatkan rumahrumah penduduk yang cenderung seragam dan dibangun dengan memperhatikan nilainilai Agama Hindu yang biasa disebut Asta Kosala-Kosali.. Kedua, program pembuatan papan nama Desa Wisata Pangsan, sebagai upaya dalam menarik minat wisatawan untuk singgah dan mencari tahu tentang atraksi-atraksi wisata yang terdapat di Desa Pangsan.. Ketiga, pembuatan papan penunjuk jalan serta peta wilayah Desa Wisata Pangsan untuk memudahkan pengunjung dalam melakukan aktivitas olah raga dan mencoba rute-rute baru yang belum pernah dilewati sebelumnya. Selain itu juga diperlukan strategi peningkatan kerjasama dan promosi, yang dilakukan dengan 2 (dua) program. Pertama, meningkatkan kerjasama dengan biro perjalanan wisata dan asosiasi pariwisata seperti ASITA (Association Of The Indonesia Tour \& Travel Agencies), HPI (Himpunan Pramuwisata Indonesia), dan PHRI (Persatuan Hotel dan Restoran Indonesia) untuk memperkenalkan Desa Pangsan secara lebih luas. Kedua, melakukan kerjasama dengan sekolah-sekolah untuk melakukan studi lapangan dengan konsep bermain sambil belajar di alam.

4. Strategi WT (Weaknesses Threats) yaitu Strategi pengembangan sumber daya manusia dan kelompok sadar wisata, yang dilakukan dengan 3 (tiga) program pengembangan. Pertama, meningkatkan kualitas sumber daya manusia dalam bidang pariwisata baik secara formal di sekolah secara informal dengan melakukan penyuluhan mengenai sadar wisata dan sapta pesona, seminar serta diskusi mengenai 
pengembangan desa wisata dan pelatihan bahasa asing dan keterampilan pariwisata. Kedua, membentuk seksi pendidikan dan pengembangan SDM dalam struktur organisasi Kelompok Sadar Wisata Mekar Buana, agar pendidikan dan peningkatan SDM dibidang pariwisata dapat dilakukan secara mandiri. Ketiga, mengadakan penyuluhan pertanian dan perkebunan, khususnya tentang pembudidayaan tanaman yang baik dan benar, serta pengetahuan tentang cara mencegah dan mengatasi penyakit yang rentan terjadi pada tanaman pertanian dan perkebunan.

\section{Simpulan}

Berdasarkan pembahasan sebelumnya, maka dapat ditarik simpulan sebagai berikut:

1. Potensi daya tarik pariwisata Desa Pangsan, dapat dibagi menjadi potensi alam yang berupa : 1). Panorama Persawahan dan Perkebunan; 2). Sungai Ayung. Sedangkan potensi budaya, terdiri dari : 1). Suasana Perdesaan dan Perumahan Penduduk; 2). Bangunan Keagamaan; 3). Goa Perlindungan; 4). Sikap Masyarakat; 5). Kesenian Tradisional; 6). Upacara Khas Desa Pangsan.

2. Lingkungan internal yang merupakan faktor-faktor kekuatan (strengths) Desa Pangsan, meliputi : 1). Panorama persawahan yang indah dan asri; 2). Irigasi pertanian dengan sistem subak; 3). Keramahtamahan masyarakat; 4). Jalur tracking; 5). Aneka vegetasi perkebunan; 6). Rafting; 7). Kehidupan tradisional masyarakat Desa Pangsan; 8). Lokasi strategis, sehingga mudah di akses dari daya tarik wisata lain. Faktor-faktor kelemahan (weaknesses) Desa Pangsan, meliputi : 1). Kurangnya Kualitas Sumber Daya Manusia; 2). Kerjasama dan promosi yang belum optimal; 3). Pengembangan potensi pariwisata Desa Pangsan yang belum optimal; 4). Kurangnya Sarana penunjang, seperti: homestay, tempat parkir, wc umum, pos jaga dll; 5). Tidak adanya souvenir khas Desa Pangsan. Lingkungan eksternal yang merupakan faktor-faktor peluang (opportunities) Desa pangsan, meliputi : 1). Adanya trend pariwisata global kearah pariwisata perdesaan; 2). Kemajuan teknologi informasi dan transportasi; 3). Citra Bali sebagai DTW dunia; 4). Program Pemkab. Badung dalam pengembangan 
desa wisata; 5). Kerjasama dengan biro perjalanan wisata, agen perjalanan wisata, dan hotel; 6). Kerjasama dengan sekolah-sekolah. Sedangkan lingkungan eksternal yang merupakan faktor-faktor ancaman (threats) Desa Pangsan, meliputi : 1). Resesi ekonomi dunia; 2). Persaingan dengan daya tarik wisata sejenis; 3). Mewabahnya penyakit rabies dan flu burung; 4). Ancaman terhadap keamanan Bali; 5). Kondisi politik dan keamanan nasional yang kurang stabil. Berdasarkan analisis lingkungan internal dan eksternal, maka dapat diketahui bahwa posisi lingkungan internal Desa Pangsan berada pada posisi sedang dengan total skor sebesar 2,808, karena berada sedikit diatas ambang batas posisi lemah dan kuatnya kawasan yang berada pada skor 2,5. Selain itu, didapatkan hasil bahwa lingkungan eksternal Desa Pangsan juga berada pada posisi sedang yaitu dengan total skor sebesar 2,710, karena berada sedikit di atas nilai skor 2,5. Setelah diplotting kedalam matriks internal dan eksternal, maka didapatkan hasil bahwa Desa Pangsan berada pada sel V yang mengindikasikan Desa Pangsan dalam kategori baik atau memiliki peluang untuk berkembang.

3. Strategi umum yang harus dilakukan dalam pengembangan Desa Pangsan sebagai desa wisata adalah strategi pertahankan dan pelihara, yaitu dengan melakukan penetrasi pasar dan pengembangan produk. Sedangkan strategi alternatif dalam pengembangan Desa Pangsan sebagai desa wisata, meliputi :

strategi pengembangan produk pariwisata, strategi penetrasi pasar, strategi pengembangan sarana dan prasarana pokok maupun penunjang pariwisata, strategi peningkatan kerjasama dan promosi, Strategi peningkatan kemanan dan kenyamanan serta memperkuat ciri khas Desa Pangsan, serta strategi pengembangan sumber daya manusia dan kelompok sadar wisata.

Dalam pengembangan Desa Pangsan sebagai desa wisata, hendaknya dilakukan dengan melibatkan seluruh stakeholders pariwisata mulai dari tahap perencanaan, pengembangan sampai dengan pengelolaan. Fokus pengembangan hendaknya dilakukan terlebih dahulu pada beberapa desa wisata yang paling berpotensi yang dapat menjadi prototype pengembangan yang ideal. Pembangunan sarana dan prasarana pendukung pariwisata hendaknya dilakukan dengan efisien dan sebisa mungkin memanfaatkan 
bangunan yang sudah ada. Kepemimpinan Kelompok Sadar Wisata Mekar Buana, seyogyanya dapat dilakukan dengan lebih netral dan transparan. Kedepan, perlu dilakukan penelitian lebih lanjut yang lebih komprehensif mengenai pengembangan Desa Pangsan.

\section{Kepustakaan}

Alwi, Hasan dan Dendy Sugono. 2005. Kamus Besar Bahasa Indonesia Edisi Ketiga. Jakarta : Balai Pustaka.

Butler, Richard W. 2006. The Tourism Area Life Cycle (Applications and Modifications). Great Britain: Cromwell Press.

Inskeep, Edward. 1991. Tourim Planning. An Integrated and Sustainable Development Approach. New York: Van Nostrand Reinhold.

Korten, David C. 1986. Community Management : Asian Experience and Perspective. Connecticut: Kumarian Press.

Marpaung, H. 2002. Pengetahuan Kepariwisataan. Bandung : Alfabeta.

Natori, Mashito. 2001. A Guide Book For Tourism Based Community Development. APTEC: Osaka-Japan.

Prastyo, 2005. Pelestarian Potensi Wisata Budaya di Desa Wisata Kabupaten Sidoarjo Jawa Timur.

Purba, Jonny. 2002. Pengelolaan Lingkungan Sosial. Yayasan Obor : Jakarta.

Wray, Meredith et. al. 2010. Sustainable Regional Tourism Destinations: Best Practice For Management, Development and Marketing. Gold Coast, Queensland: CRC for Sustainable Tourism Pty Ltd.

Yoeti, Oka A. 2008. Perencanaan dan Pengembangan Pariwisata. Jakarta : PT Pradya Paramita. 